\title{
Kuinka paljon viherkesanto- ja hoidettu viljelemätön pelto -lohkoilla olisi satoa biokaasun tuotantoon?
}

\author{
Oiva Niemeläinen ${ }^{1}$, Elina Virkkunen ${ }^{2}$ Lauri Jauhiainen $^{1}$ ja Timo Lötjönen ${ }^{1}$ \\ ${ }^{1}$ MTT Kasvintuotanto , MTT Planta, 31600 Jokioinen, oiva.niemelainen@mtt.fi \\ ${ }^{2}$ MTT Kotieläintutkimus, Alueet, Kipinäntie 16, 88600 Sotkamo, elina.virkkunen@mtt.fi
}

\section{Tiivistelmä}

Suomessa on sellaisia "Hoidettu viljelemätön pelto" (HVP) ja viherkesantopeltoja lähes 190000 ha, joilta kasvimassa voitaisiin hyödyntää esimerkiksi biokaasuntuotantoon. HVP -lohkojen viljelytoimissa mm. lannoittamisessa on rajoituksia. Pääasiassa kasvustot ovat monivuotisia nurmia. HVP- peltojen ala on suuri suhteessa ruokohelpin viljelyalaan bioenergian tuotannossa (16 620 ha). Hoidetun viljelemättömän pellon ja suojavyöhykenurmen käytöllä on vesistöjen suojeluun ja viljelyn monimuotoisuuteen liittyviä tavoitteita. Olisiko ohjelmien eri tavoitteet mahdollista saavuttaa vaikka sato hyödynnettäisiin esim. biokaasun tuotannossa?

Olisiko HVP peltojen sadon määrä riittävä ja sen laatu sovelias biokaasulaitosten syötteeksi? "Hoidettu viljelemätön pelto biokaasuksi" -hankkeessa kartoitetaan viljelijöiden pelloilta kerättyjen näytteiden avulla biomassan määrä ja sen laatu. Hankkeessa tehdään arvioita myös biomassan korjuu- ja varastointikustannuksista. Tässä esityksessä raportoidaan vuosina 2010 ja 2011 maatiloilta haettujen näytteiden perusteella biomassan määrää ja laatua viherkesannoilla, luonnonhoitonurmilla ja suojavyöhykkeillä. Näytteitä haettiin Etelä-Suomessa Jokioisista käsin ja Pohjois-Suomessa Sotkamosta käsin. Biomassasadon määrä vaihteli suuresti lohkojen välillä. Vuoden 2010 tulosten mukaan eteläisen otanta-alueen luonnonhoitonurmien lohkojen sato $(\mathrm{n}=27)$ oli keskimäärin $5540 \mathrm{~kg}$ kuiva-ainetta/ha (vaihteluväli 1330-10300 kg ka/ha. Pohjoisen otanta-alueen (n=16) sato oli keskimäärin $4280 \mathrm{~kg} \mathrm{ka/ha}$ (vaihteluväli 2170-8530 kg ka/ha). Viherkesantopeltojen vastaavat arvot olivat eteläisellä otanta-alueella $4100 \mathrm{~kg} \mathrm{ka} / \mathrm{ha}$ (vaihteluväli 1720-7760 kg ka/ha; n=18) ja pohjoisella otanta-alueella $4050 \mathrm{~kg} \mathrm{ka} / \mathrm{ha}$ (vaihteluväli 2450-6120 kg ka/ha; n=9).

Vuoden 2010 näytteiden analyysitulosten perusteella laskettuna olisi pelloilta poistunut 7-10 kg fosforia hehtaaria kohti jos sato olisi korjattu. Sadon mukana poistunut typpimäärä olisi ollut 40-70 kg N/ha. Noin kaksi kolmasosaa tuoresadon määrästä oli heinäkasveja. Vuoden 2011 tuloksista on käytettävissä kuiva-ainesadot ja botaaninen koostumus. Vuonna 2011 eteläisen otanta-alueen luonnonhoitonurmien lohkojen sato $(\mathrm{n}=40)$ oli keskimäärin $5430 \mathrm{~kg} \mathrm{ka} / \mathrm{ha}$ (vaihteluväli 3000-10260 kg ka/ha. Pohjoisen otanta-alueen $(\mathrm{n}=20)$ sato oli keskimäärin $4690 \mathrm{~kg}$ ka/ha (vaihteluväli 2140-7130 kg $\mathrm{ka} / \mathrm{ha}$ ). Viherkesantopeltojen vastaavat arvot olivat eteläisellä otanta-alueella $5120 \mathrm{~kg} \mathrm{ka} / \mathrm{ha}$ (vaihteluväli 1850-8780 kg ka/ha; n=23) ja pohjoisella otanta-alueella $4330 \mathrm{~kg} \mathrm{ka/ha} \mathrm{(vaihteluväli} \mathrm{2270-6260} \mathrm{kg} \mathrm{ka/ha;}$ $\mathrm{n}=15)$.

HPV-peltojen lohkokoko on sangen pieni. Valtaosa HVP-lohkojen kokonaispinta-alasta kuitenkin muodostuu lohkojen koon perusteella luokiteltuna suurimman neljänneksen lohkojen pinta-alasta. Maatalousviraston vuoden 2010 lohkotietoaineiston perusteella 60,4 prosenttia eli 78111 ha luonnonhoitonurmen kokonaisalasta 129370 ha muodostui lohkoista joiden koko oli vähintään 1,45 ha. Viherkesantoalasta 62,4 prosenttia eli 27441 ha muodostui lohkoilta joiden pinta-ala on vähintään 1,61 ha.

Asiasanat: bioenergia, biokaasu, biomassa, fosfori, lohkokoko, luonnonhoitonurmi, suojavyöhyke, typpi, viherkesanto. 


\section{Johdanto}

Suomenssa oli vuonna 2010 "Hoidettu viljelemättömän pelto" (HVP) kategoriassa peltoja 163000 ha. Syntyneen biomassan hyödyntäminen pellon ulkopuolella on mahdollista muilla tämän peltoluokan kategorioilla paitsi "Riistapelto" (24500 ha). Biomassan hyödyntäminen on mahdollista myös viherkesannoilta (44000 ha) ja suojavyöhykkeiltä (7500 ha) (ANON. 2009 ja ANON. 2011). Peltoalaa, jolta sato voitaisiin hyödyntää on runsaat 190000 ha. Hoidetun viljelemättömän pellon, viherkesannon ja suojavyöhykkeiden käytöllä on vesien suojeluun ja viljelyn monimuotoisuuteen liittyviä tavoitteita. Olisiko ohjelmien eri tavoitteet mahdollista saavuttaa vaikka sato hyödynnettäisiin esim. biokaasun tuotannossa?

Prochnowin ym. (2009) mukaan nurmibiomassat sopivat hyvin biokaasulaitosten syötteeksi vaikkakin nurmimassan käytössä on havaittu teknisiä ongelmia. Heinäbiomassoista saadaan biokaasutuksella energiaa noin 3 MWh/ kuiva-ainetonni (Lehtomäki 2006). MTT:n ”Hoidettu viljelemätön pelto biokaasuksi” -hankkeen tavoitteena on selvittää minkä suuruinen ja -laatuinen biomassa muodostuu eri HVP-pellonkäyttökategorioiden pelloille. Näitä ovat $\mathrm{mm}$. luonnonhoitopelto (monivuotinen nurmi), viherkesanto sekä suojavyöhykkeet. Lisäksi arviodaan sadon korjuun kustannuksia, vaikutuksia ravinnevirtoihin ja huuhtoutumisriskeihin ja arviodaan näiden peltojen merkitystä kasvilajiston monimuotoisuudelle ja ekosysteemipalveluille. Lisäksi tuotetaan ehdotuksia hoito-ohjeistukseksi mahdollisimman tehokasta biomassan tuotantoa varten siten, että samalla saavutetaan ao. ohjelmille asetetut muut tavoitteet. Tässä kirjoituksessa esitetään kahden ensimmäisen tutkimusvuoden tuloksia maatiloilta haettujen näytteiden perusteella sadon määrästä ja koostumuksesta sekä lohkokokotarkastelun tuloksia korjuun kannalta. Hanke jatkuu ja tässä esitettävät tulokset ovat alustavia välituloksia.

\section{Aineisto ja menetelmät}

Otantatutkimuksen tekemistä varten saatiin Maaseutuvirastolta hoidettu viljelemätön pelto -kategorioiden (viherkesanto, luonnonhoitopellon eri käyttöluokat) sekä suojavyöhykenurmen ja viherlannoitusnurmen kasvulohkotiedot pinta-aloineen koko maasta ja yhteystietoineen Forssan, Hämeenlinnan, Riihimäen, Kajaanin, Kehys-Kainuun, Etelä-Pirkanmaa, Loimaan, Salon seutukuntien sekä Karkkilan, NummiPusulan, Vihdin, Vieremän, Sonkajärven, Iisalmen, Rautavaaran ja Nurmeksen kuntien alueelta.

Kasvulohkojen koon perusteella rajattiin pienin neljännes otannan ulkopuolelle. Otokseen tulevan lohkon minimikooksi rajautui: viherkesanto 0,39 ha; luonnonhoitopelto (nurmikasvit vähintään 2 v) 0,38 ha; suojavyöhykenurmi 0,44 ha. Loput kolme lohkokoon perusteella muodostettua neljännestä muodostivat kolme pinta-alaluokkaa, jotka otettiin otannassa huomioon. Lisäksi otanta-alue jaettiin ensin neljään osaalueeseen: kolme Jokioisista (eri suuntiin Jokioisista) ja yksi Sotkamosta tehtävää näytteiden hakua varten. Ositteita olivat alue ja pinta-alaluokka -kombinaatiot (4x3). Otanta tehtiin kullekin pellon käyttöluokalle erikseen. Kustakin ositteesta poimittiin yksinkertaisella satunnaisotannalla samansuuruinen otos. Satunnaisotantaan tuli Jokioisten keräysalueelta 80 viherkesanto-, 80 HVP monivuotinen nurmi-ja 29 suojavyöhykenurmilohkoa eli yhteensä 199 lohkoa. Sotkamon keräysalueelle tuli 27 viherkesanto-, 26 HVP monivuotinen nurmi- ja 19 suojavyöhykenurmilohkoa eli yhteensä 73 lohkoa. Otantaa täydennettiin haettujen näytteiden jakauman perusteella vuodeksi 2011. Etelä-Suomen kolme otanta-aluetta yhdistetään tulosten käsittelyssä ja raportoinnissa.

Haettavien näytteiden lukumäärätavoitteeksi asetettiin Sotkamon osalta 40 lohkoa ja Jokioisten osalta 80 lohkoa. Sotkamosta näytteet haettiin vuonna 201039 lohkolta ja Jokioisista käsin 56 lohkolta. Yhteensä näytteitä saatiin v. 201095 lohkolta. Vuonna 2011 Jokioisten keräysalueelta haettiin näyte 73 lohkolta ja Sotkamosta käsin 41 lohkolta. Näytteiden keruu ajoittui noin puolentoista kuukauden ajalle. Valtaosa näytteistä haettiin heinäkuun puolivälin ja elokuun lopun välisenä aikana.

Kultakin lohkolta otettiin neljä satomittausta $(4 \mathrm{~m}$ pitkä ja $90 \mathrm{~cm}$ leveä kaista itsevetävällä sormiteräniittokoneella niitettynä), josta tehtiin edustava yhdistetty näyte sadon botaanista analyysiä ja laatumäärityksiä varten. Näytteistä on tehty kuiva-ainemääritys ja tuoreesta sadosta on tehty botaaninen määritys kolmeen luokkaan: heinäkasvit, palkokasvit, leveälehtiset rikat. Kultakin lohkolta otetiin lisäksi maanäyte normaalia viljavuusanalyysiä varten, että 2,5 cm:n pintamaakerroksesta. Vuonna 201157 lohkolla tehtiin myös tarkempi kasvillisuuden monimuotoisuuskartoitus ja otettiin näyte maan siemenpankin määrittämistä varten (tuloksia ei esitetä tässä). Analyysit vuoden 2010 näytteistä on pääosin tehty ja vuoden 2011 näytteiden analysointi on käynnissä. Satonäytteestä tehtiin kaasuntuotannon kannalta keskeisin ominaisuus kuiva-aine (TS=total solids) ja hehkutushäviö eli orgaaninen aine (VS=volatile solids= kuiva-aine, josta vähennetään tuhka=orgaaninen aines). Kaikista näytteistä tehtiin kivennäismääritys 
ja osasta vuoden 2010 näytteistä määritettiin myös typpipitoisuus ja orgaanisen aineen sellulaasiliukoisuus.

\section{Alustavat tulokset ja tulosten tarkastelu}

Tässä esitettävät tulokset ovat vasta alustavia koska tutkimus jatkuu vielä vuoden 2012. Data analysoidaan yksityiskohtaisemmin kun koko aineisto laatu- ja maa-analyyseineen ja lohkojen viljelyn taustatietoineen ovat käytettävissä. Tässä esitetään tuloksia kuiva-ainesadon määrästä ja kasvuston koostumuksesta sekä yhden vuoden tuloksiin perustuva alustava arvio sadon mukana siirtyvästä typen ja fosforin määrästä. Lisäksi esitetään tuloksia lohkojen koosta.

\section{HVP -lohkojen koosta}

Koko maan vuoden 2010 peltolohkoaineiston avulla tarkasteltiin nyt tarkastelussa olevien pellon käyttöluokkien lohkojen kokoa ja lukumääriä. Lohkot luokiteltiin lukumäärän perusteella neljään kvartaaliin 0-25\%, 25-50\%, 50-75\% ja 75-100\%. Pienimmän neljänneksen yläraja ja suurimman neljänneksen alaraja (ha) olivat eri käyttöluokissa seuraavat: luonnonhoitopelto (nurmikasvit vähintään 2 v) 0,38 ja 1,45 ha; viherkesanto 0,39 ja 1,61 ha, ja suojavyöhykenurmi 0,44 ja 1,45 ha. Yli 60 prosenttia kaikkien kolmen käyttöluokan pinta-alasta muodostuu kooltaan suurimman kvartaalin lohkoista (Taulukko 1). Suurimman kvartaalin luokkien pinta-alakertymä on huomattavan suuri: yli 78000 ha luonnonhoitonurmella ja yli 27000 ha viherkesannolla eli runsaat 105000 ha. Lohkot ovat kooltaan vähintään 1,45 ha. On oletettavaa, että lohkokoon suureneminen edesauttaa hehtaarikohtaisten korjuukustannusten alenemista (Nielsen \& Mortensen 2001).

Taulukko 1. Pinta-alakertymä (ha) koko maassa lohkojen eri kokoluokissa.

\begin{tabular}{|l|l|l|l|l|l|}
\hline & Lohkoja & \multicolumn{4}{|l|}{$\begin{array}{l}\text { Lohkojen jakautuminen lukumäärän perusteella eri kokoluokkiin } \\
\text { pienimmästä suurimpaan ja pinta-ala kussakin luokassa (ha) }\end{array}$} \\
\hline & & $0-25 \%$ & $25-50 \%$ & $50-75 \%$ & $75-100 \%$ \\
\hline LHP nurmi & 113912 & 6174 & 15437 & 29647 & 78113 \\
\hline Viherkesanto & 34012 & 1787 & 4931 & 9790 & 27441 \\
\hline Suojavyöhyke & 6212 & 341 & 847 & 1601 & 4656 \\
\hline
\end{tabular}

Lisäksi tarkasteltiin kuinka suuren osan HVP-lohkot (tarkastelussa käytettiin luonnonhoitonurmea) muodostivat koko peruslohkon pinta-alasta. Kooltaan pienillä (luokat $<1$ ha ja 1-5 ha) peruslohkoilla HVPkasvulohko oli lähes vastaavan kokoinen kuin peruslohkokin. Sen sijaan yli 10 hehtaarin peruslohkoilla yli 50 prosentilla lohkoista HVP-ala oli alle 10 prosenttia peruslohkon alasta. Otanta-alueelta - mistä oli käytettävissä myös viljelijätiedot - tarkasteltiin kuinka paljon HVP-alaa yksittäisillä viljelijällä on. Yksittäisellä viljelijällä oli luonnonhoitonurmialaa keskimäärin 3,6 ha, viherkesantoa 2,6 ha ja suojavyöhykenurmea 2,6 ha kukin kategoria itsenäisesti laskettuna. Kun luonnonhoitonurmi- ja viherkesantoalaa tarkasteltiin samalla kertaa, oli niitä tilalla yhteensä keskimäärin 3,9 ha. Kun tarkasteltiin suurimman neljänneksen tiloja (kukin kategoria itsenäisesti) oli luonnonhoitonurmialaa vähintään 6,7 ha, viherkesantoalaa 5,3 ha ja suojavyöhykenurmia 4,8 ha. Tarkasteltaessa suurimman neljänneksen tiloilla luonnonhoitonurmi ja viherkesantoalaa oli yhteensä vähintään 7,3 ha.

\section{Biomassasadon määrästä}

Näytteiden keruu ajoittui noin puolentoista kuukauden ajalle. Näytteet haettiin heinäkuun puolivälin ja elokuun lopun välisenä aikana. Maaseutuviraston hoito-ohjeet ohjeistavat ao. lohkojen niiton tehtäväksi suhteellisen myöhään kasvukaudella (ANON. 2011). Melko paljon kasvustoja oli niitetty jo heti heinän korjuun jälkeen.

Satovaihtelu eri lohkojen välillä oli suurta. Pienin korjattu sato oli $1330 \mathrm{~kg} \mathrm{ka/ha} \mathrm{ja} \mathrm{suurin} 10300 \mathrm{~kg}$ ka/ha (Taulukko 2). Tässä vaiheessa ei ole vielä analysoitu näytteiden hakuajankohdan ja lohkojen taustatekijöiden vaikutusta tuloksiin ja tuloksista esitetään keskiarvot, keskihajonnat ja pienimmän ja suurimman havainnon arvot vuosittain, koepaikoittain ja otanta-alueittain.

Taulukko 2. Kuiva-ainesadon keskiarvo, keskihajonta ja suurin ja pienin arvo lohkon käyttöluokittain vuosina 2010 ja 2011 Jokioisten (Jo) ja Sotkamon (So) otanta-aluella. 


\begin{tabular}{|l|l|l|l|l|l|l|}
\hline $\begin{array}{l}\text { Paikka ja } \\
\text { käyttö }\end{array}$ & Vuosi & $\begin{array}{l}\text { Havaintoja } \\
\mathrm{kpl}\end{array}$ & $\begin{array}{l}\text { Keskiarvo } \\
\mathrm{kg} \mathrm{ka} / \mathrm{ha}\end{array}$ & $\begin{array}{l}\text { Keskihaj. } \\
\mathrm{kg} \mathrm{ka} / \mathrm{ha}\end{array}$ & $\begin{array}{l}\text { Pienin } \\
\mathrm{kg} \mathrm{ka} / \mathrm{ha}\end{array}$ & $\begin{array}{l}\text { Suurin } \\
\mathrm{kg} \mathrm{ka} / \mathrm{ha}\end{array}$ \\
\hline Jo LHN & 2010 & 27 & 5540 & 2135 & 1330 & 10300 \\
\hline Jo LHN & 2011 & 40 & 5430 & 1710 & 3000 & 10260 \\
\hline So LHN & 2010 & 16 & 4280 & 1675 & 2170 & 8530 \\
\hline So LHN & 2011 & 20 & 4690 & 1390 & 2140 & 7130 \\
\hline Jo Viherk. & 2010 & 18 & 4100 & 1400 & 1720 & 7760 \\
\hline Jo Viherk. & 2011 & 23 & 5120 & 1725 & 1850 & 8780 \\
\hline So Viherk. & 2010 & 9 & 4050 & 1341 & 2450 & 6120 \\
\hline So Viherk. & 2011 & 15 & 4330 & 1500 & 2270 & 6260 \\
\hline Jo Suojav. & 2010 & 4 & 3950 & 469 & 3450 & 4520 \\
\hline Jo Suojav. & 2011 & 10 & 5160 & 1860 & 2330 & 9370 \\
\hline So Suojav. & 2011 & 6 & 3780 & 1550 & 1380 & 5320 \\
\hline
\end{tabular}

Taulukko 3. Sadon botaaninen koostumus prosentteina tuoresadon perusteella määritettynä. Havaintomäärät ovat samat kuin taulukossa 2.

\begin{tabular}{|l|l|l|l|l|l|l|l|}
\hline $\begin{array}{l}\text { Paikka ja } \\
\text { käyttö }\end{array}$ & Vuosi & Heinä -\% & $\begin{array}{l}\text { Keski- } \\
\text { hajonta }\end{array}$ & $\begin{array}{l}\text { Palko- } \\
\text { kasvi-\% }\end{array}$ & $\begin{array}{l}\text { Keski- } \\
\text { hajonta }\end{array}$ & $\begin{array}{l}\text { Leveälehtiset } \\
\text { rikat-\% }\end{array}$ & $\begin{array}{l}\text { Keski- } \\
\text { hajonta }\end{array}$ \\
\hline Jo LHN & 2010 & 66 & 26 & 23 & 25 & 11 & 19 \\
\hline Jo LHN & 2011 & 63 & 14 & 11 & 12 & 26 & 13 \\
\hline So LHN & 2010 & 76 & 24 & 5 & 11 & 19 & 21 \\
\hline So LHN & 2011 & 76 & 23 & 7 & 15 & 17 & 20 \\
\hline Jo Viherk. & 2010 & 65 & 30 & 23 & 32 & 12 & 16 \\
\hline Jo Viherk. & 2011 & 64 & 21 & 13 & 13 & 23 & 18 \\
\hline So Viherk. & 2010 & 75 & 20 & 16 & 15 & 9 & 15 \\
\hline So Viherk. & 2011 & 73 & 24 & 12 & 21 & 15 & 12 \\
\hline Jo Suojav. & 2010 & 71 & 18 & 11 & 16 & 18 & 19 \\
\hline Jo Suojav. & 2011 & 62 & 23 & 10 & 10 & 28 & 22 \\
\hline So Suojav. & 2011 & 70 & 12 & 3 & 3 & 27 & 11 \\
\hline
\end{tabular}

Noin kaksi kolmasosaa biomassasta oli heinää (Taulukko 3). Palkokasvien keskimääräinen osuus oli alle neljänneksen (Taulukko 3). Leveälehtisten rikkakasvien määrä vaihteli palkokasvien määrää enemmän ja oli useissakin kohteissa suurempi kuin neljännes koko kasvimassan määrästä.

Prochnowin ym. (2009) mukaan nurmibiomassojen syötespesifiset metaanisadot nousevat korjuun aikaistuessa kun taas pinta-ala spesifiset metaanisadot nousevat hehtaarikohtaisten biomassasatojen kohotessa. Muodostuneen biomassan korjuun kannattavuuteen vaikuttaa olennaisesti biomassan määrä ja käyttöarvo, koska esim. korjuu-urakoinnissa käytetään usein hehtaaritaksoja. Nurmikasvusto voi tuottaa suuriakin satoja lannoittamattoman jakson alussa. Muun muassa Pahkalan ym. (1996) agrokuitututkimuksessa nurmet tuottivat kylvön jälkeisenä vuonna lannoittamattomina Jokioisissa 6,4-7,6, Vihdissä 8,3-9,6 ja Ruukissa 5,8-8,8 t ka/ha. Pitkäikäisistä lannoittamattomista nurmista ei satotietoja ole käytettävissä, mutta Hokkanen ja Raatikainen (1977) kartoittivat 1-6 vuotta pakettipeltoina olleiden peltojen kasvimassaa Jyväskylän seudulla. Maanpäällistä vihermassaa oli keskimäärin 2735 kg /ha ja lisäksi kuollutta materiaalia $1300 \mathrm{~kg} / \mathrm{ha}$ eli maan pinnan yläpuolella olevaa kasvimassaa oli $4000 \mathrm{~kg} / \mathrm{ha}$. Raatikaisen ja Raatikaisen (1975) nurmen satoisuutta määrittäneessä tutkimuksessa heinäsato oli keskimäärin 3700 kg/ha. Typpilannoitus kartoitetuilla pelloilla oli alle $50 \mathrm{~kg} \mathrm{~N} / \mathrm{ha} / \mathrm{v}$. Tässä mitatut keskisadot ovat samaa suuruusluokkaa. Tässä todettu vaihtelu oli huomattavan suurta. Mitkä tekijät aiheuttivat vaihtelua (esim. nurmen ikä, korjuun ajankohta) selvinnee kun satotulosten taustatiedot liitetään saatuihin satotuloksiin koko aineiston valmistuttua.

Heinäbiomassoista saadaan biokaasutuksella energiaa noin $3 \mathrm{MWh} /$ kuiva-ainetonni (Lehtomäki 2006). os hoidetun viljelemättömän pellon heinäsadon arvioidaan olevan 4 ton ka/ha, niin energiaa tästä saataisiin $12 \mathrm{MWh} / \mathrm{ha}$. Biokaasusähköksi muunnettuna (hyötysuhde 33 \%) tämä vastaisi $4 \mathrm{MWh} / \mathrm{ha}$, jonka arvo maatilan omassa käytössä olisi noin 400 e/ha. Lisäksi saadaan lämpöenergiaa.

Energian tuotannon lisäksi HVP-peltojen sadon korjaamisella voi olla myönteisiä tai kielteisiä 
vaikutuksia muihin tavoitteisiin johon ympäristötukiohjelmalla pyritään. Viherkesantojen ja suojavyöhykkeiden monimuotoisuusvaikutuksista on jonkun verran tutkimustietoa olemassa (Hyvönen 2007, Salonen ym. 2007). Sen sijaan Hoidettu viljelemätön pelto -kategoriassa olevista pelloista ei ole tietoa. Niillä on kuitenkin potentiaalisesti suuri merkitys monimuotoisuudelle johtuen niiden kesantomaisesta luonteesta ja suuresta pinta-alasta esim. verrattuna ympäristötuen piirissä oleviin viherkesantoihin. Ravinteiden huuhtoutumisen kannalta sadonkorjuun vaikutukset voivat olla moninaiset.

Taulukko 4. Arvio sadon mukana poistuva fosforin ja typen määrästä. Alustavia tuloksia vuoden 2010 näytteistä (suluissa näytelohkojen lukumäärä joista analyysit on tehty):

Sadon laskennallinen typpi- ja fosfori poistuma olisi ollut v. 2010 (kg/ha):

\begin{tabular}{lllll} 
& \multicolumn{2}{c}{ Typpi (kg N/ha) } & \multicolumn{2}{l}{ Fosfori (kg P/ha) } \\
\cline { 2 - 5 } & Jokioinen & Sotkamo & Jokioinen & Sotkamo \\
LHN nurmi & $72(27)$ & $62(16)$ & 9,2 & 10,1 \\
Viherkesanto & $58(18)$ & $53(9)$ & 6,7 & 7,7 \\
Suojavyöhyke & $39(4)$ &. & 6,9 &.
\end{tabular}

Nurmiviljely vähentää eroosioriskiä, mutta saattaa lisätä liuenneen fosforin kuormaa kevään pintavalunnassa (Turtola 1993, Bechmann ym. 2005, Uusi-Kämppä \& Jauhiainen 2010). Esimerkiksi suojavyöhykkeiltä, joilta kasvillisuutta ei niitetty ja korjattu, liuenneen fosforin määrä kasvoi kevään sulamisvesissä (Uusi-Kämppä ym. 2011). Syynä oli fosforin vapautuminen kasvisoluista. Ensimmäisen syyshallan jälkeen suojavyöhykkeen maanpäällisessä biomassassa havaittiin fosforimäärän vähentyneen jopa 6 kg/ha (Räty ym. 2009). Pintavalumaveteen liuennut fosfori oli peräisin pakkasen rikkomista kasvisoluista ja maan pintakerrokseen kertyneestä fosforista. Fosforikuormitusta voitaisiin pienentää korjaamalla vuosittain osa maanpäällisestä kasvimassasta. Heinien ja luonnonvaraisten kasvien fosforimäärä oli suurimmillaan kukinnan aikana ja heti sen jälkeen (Uusi-Kämppä \& Kilpinen 2000). Siten suojavyöhykkeen tai luonnonhoitopellon niittoajankohdalla on merkitystä, kun kasvillisuuden mukana halutaan poistaa pellolta mahdollisimman paljon fosforia.

\section{Johtopäätökset}

- HVP-lohkoilta saadun biomassan määrä vaihteli huomattavasti (1330-10300 kg ka/ha). On siis sellaisiakin HVP-lohkoja, joilla on huomattavan suuri sato hyödynnettäväksi.

- Heinäkasvien osuus maanpäällisestä biomassasta oli noin kaksi kolmasosaa.

- Valtaosa HVP-peltojen pinta-alasta muodostuu lohkoilta joiden pinta-ala on vähintään 1,45 ha. Pienillä lohkoilla korjuutyö on suuria lohkoja hitaampaa. Tilanne on kohtalaisen hyvä, sillä työntutkimusten mukaan säilörehun ja oljen korjuun työmenekki ei enää merkittävästi pienene, kun lohkokoko ylittää koneketjusta riippuen 2-3 ha (Klemola ym. 2002, Nielsen \& Mortensen 2001). Alle 1 ha:n lohkoilla työmenekki on suurimmillaan.

Kirjallisuus

ANON. 2009. Hakuopas. 2009. Tilatuki. Maatalouden ympäristötuki. Luonnonhaittakorvaus. Kansalliset tuet. Maaseutuvirasto. Elektroninen julkaisu. 148 p. http://www.mavi.fi/fi/index/viljelijatuet/oppaatjaohjeet/hakuopas.html

ANON. 2011. Hakuopas. 2011. Tilatuki, Maatalouden ympäristötuki. Luonnonhaittakorvaus, Kansalliset tuet. Maaseutuvirasto. Elektroninen julkaisu. 156 p.

http://www.mavi.fi/attachments/mavi/viljelijatuet/hakuopas/5wOT3BjZz/Hakuopas2011.PDF

Bechmann, M.E, Kleinman, P.J.A., Sharpley, A.N., Saporito, L.S., 2005. Freeze-thaw effects on phosphorus loss in runoff from manured and catch-cropped soils. J. Environ. Qual. 34, 2301-2309.

Hokkanen, H. and M. Raatikainen, 1977. Yield, vegetation and succession in reserved fields in Central Finland. J. Sci. Agric. Soc. Finland 49: 221-238. 
Hyvönen, T. 2007. Kesantojen kasvilajiston monimuotoisuus ja siemenravinnon tuotto linnuille. In: Jukka Salonen, Marjo Keskitalo ja Marjo Segersvedt (tom.). Peltoluonnon ja viljelyn monimuotoisuus. Maa- ja elintarviketalous 110 : s. $13-25$.

Klemola, E., Karttunen, J., Kaila, E., Laaksonen, K. ja Kirkkari, A.-M. 2002. Lohkon koon ja muodon taloudelliset vaikutukset. Työtehoseuran julkaisuja 386. $48 \mathrm{~s}$.

Lehtomäki, A. 2006. Biogas Production from Energy Crops and Crop Residues. Jyväskylä Studies in Biological and Environmental Science 163. Academic Dissertation. Jyväskylä: University of Jyväskylä, 91 p.

Nielsen, V. and Mortensen, H. S. 2001. Baling of straw into round bales or mini big bales. DJF rapport nr. 57. Danmarks JordbruksForskning. 33 p.

Pahkala, K., Mela, T., Hakkola, H., Järvi, A. ja Virkajärvi, P. 1996. Agrokuidun tuotanto ja käyttö Suomessa. Tutkimuksen loppuraportti, I osa. Agrokuitukasvien viljely. Maatalouden tutkimuskeskuksen julkaisuja. Sarja A. 3. $68 \mathrm{~s}$.

Prochnow, A., Heiermann, M., Phlöchl, M., Linke, B., Idler, C., Amon, T. and P.J. Hobbs. 2009. Bioenergy from permanent grassland - A review: 1. Biogas. Bioreource Technology 100: 4931-4944.

Raatikainen, M. ja T. Raatikainen, 1975. Heinänurmien sato, kasvilajikoostumus ja sen muutokset. Annales Agriculturae Fenniae 14. 57-191.

Räty, M., Uusi-Kämppä, J., Yli-Halla, M., Rasa, K. \& Pietola, L. 2009. Phosphorus and nitrogen cycles in the vegetation of differently managed buffer zones. Nutrient Cycling in Agroecosystems DOI 10.1007/s10705-009-92774

Salonen, J., Keskitalo, M. ja M. Segerstedt. 2007. Peltoluonnon ja viljelyn monimuotoisuus. Maa- ja elintarviketalous 110. $331 \mathrm{~s}$.

Sharpley, A.N., Smith, S.J. \& Menzel, R.G. 1986. Phosphorus criteria and water quality management for agricultural watersheds. Lake and Reservoir Management. 2:177-182.

Turtola, E. 1993. Phosphorus and nitrogen leaching during set-aside No. 228. In: Edited by Paavo Elonen ja Jyrki Pitkänen. Proceedings of NJF-seminar no. 228 : Soil Tillage and Environment : Jokioinen, Finland, June 8-10, 1993. NJF-Utredning. Rapport 88: 207-217.

Uusi-Kämppä. J. ja M. Kilpinen. 2000. Suojakaistat ravinnekuormituksen vähentäjinä. Maatalouden tutkimuskeskuksen julkaisuja Sarja A 83. 49 p.

Uusi-Kämppä, J. \& Jauhiainen, L. 2010. Long-term monitoring of buffer zone efficiency under different cultivation techniques in Boreal conditions. Agriculture, Ecosystems and Environment. 137: 78-85. doi:10.1016/j.agee.2010.01.002

Uusi-Kämppä, J., E. Turtola, A. Närvänen, L. Jauhiainen and R. Uusitalo. 2011. Phosphorus mitigation during springtime runoff by amendments applied to grassed soil. J. of Environmental Quality 40: X-x. 